\title{
High-Resolution Fourier-Transform IR Spectroscopic Determination of Impurities in Silicon Tetrafluoride and Silane Prepared from It
}

\author{
L. A. Chuprov ${ }^{a}$, P. G. Sennikov ${ }^{a}$, K. G. Tokhadze ${ }^{b}$, \\ S. K. Ignatov ${ }^{c}$, and O. Schrems ${ }^{d}$ \\ ${ }^{a}$ Institute of Chemistry of High-Purity Substances, Russian Academy of Sciences, \\ ul. Tropinina 49, Nizhni Novgorod, 603950 Russia \\ ${ }^{b}$ Institute of Physics (Petrodvorets Branch), St. Petersburg State University, \\ ul. Ulyanovskaya 1, Petrodvorets, 198504 Russia \\ ${ }^{c}$ Lobachevski State University, pr. Gagarina 23, Nizhni Novgorod, 603600 Russia \\ ${ }^{d}$ Alfred Wegener Institute Foundation for Polar and Marine Research, Bremerhaven, 27570 Germany \\ e-mail: churbanov@ihps.nov.ru \\ Received February 15, 2006
}

\begin{abstract}
The impurity compositions of silicon tetrafluoride and silane prepared from it have been determined by high-resolution Fourier-transform IR spectroscopy. In the spectra of $\mathrm{SiF}_{4}$ samples differing in purity, we have identified rovibrational bands arising from $\mathrm{Si}_{2} \mathrm{~F}_{6} \mathrm{O}, \mathrm{SiF}_{3} \mathrm{OH}, \mathrm{HF}, \mathrm{SiF}_{3} \mathrm{H}, \mathrm{SiF}_{2} \mathrm{H}_{2}, \mathrm{SiH}_{3} \mathrm{~F}, \mathrm{CH}_{4}, \mathrm{CO}_{2}$, and $\mathrm{CO}$ impurities. Their detection limits lie in the range $9 \times 10^{-5}\left(\mathrm{CO}_{2}\right)$ to $3 \times 10^{-3} \mathrm{~mol} \%\left(\mathrm{Si}_{2} \mathrm{~F}_{6} \mathrm{O}\right)$. In the spectra of $\mathrm{SiH}_{4}$ samples of different purity, we have detected $\mathrm{CH}_{4}, \mathrm{CO}_{2}, \mathrm{SiF}_{3} \mathrm{H}, \mathrm{SiF}_{2} \mathrm{H}_{2}$, and $\mathrm{SiF}_{4}$ impurities. Their detection limits lie in the range $8 \times 10^{-5}\left(\mathrm{CO}_{2}\right)$ to $1 \times 10^{-3} \mathrm{~mol} \%\left(\mathrm{SiF}_{4}\right)$.
\end{abstract}

DOI: $10.1134 / \mathrm{S} 0020168506080231$

\section{INTRODUCTION}

Silicon tetrafluoride, $\mathrm{SiF}_{4}$, is a large-scale by-product in the manufacture of phosphoric fertilizers and some ore dressing processes [1]. On the other hand, silicon tetrafluoride has recently received considerable attention as one of the cheapest and most attractive precursors to silicon, which is being used increasingly in industrial applications. Unfortunately, the procedures proposed to date are inferior in efficiency and cost to the existing industrial processes for silicon manufacturing [2]. At the same time, in the approach recently developed by Devyatykh et al. [3] for producing isotopically enriched ${ }^{28} \mathrm{Si},{ }^{29} \mathrm{Si}$, and ${ }^{30} \mathrm{Si}$ - thermal decomposition of an appropriate isotopically enriched silanesilicon tetrafluoride is essentially the only silicon-containing volatile precursor with consideration for the known advantages of using volatile fluorides in centrifugal isotopic enrichment processes. The key steps of this approach are the synthesis and purification of silicon tetrafluoride, isotopic enrichment, conversion to isotopically enriched silane, purification and decomposition of the silane, and preparation of polycrystalline silicon-from several grams for the rare isotopes ${ }^{29} \mathrm{Si}$ and ${ }^{30} \mathrm{Si}$ to hundreds of grams and, in the future, several kilograms for ${ }^{28} \mathrm{Si}$.
In devising processes for the synthesis and purification of isotopically enriched $\mathrm{SiF}_{4}$ and $\mathrm{SiH}_{4}$, an important issue is the ability to monitor a number of impurities in these substances, primarily those containing hydrogen, oxygen, and carbon.

High-resolution (up to $0.01 \mathrm{~cm}^{-1}$ ) Fourier-transform IR (FTIR) spectroscopy is used rather rarely to determine impurities in the gas phase, primarily because only a limited number of laboratories have appropriate vacuum instruments at their disposal. In contrast to diode laser spectroscopy, this method provides information about the chemistry and state (clustering, complexing, adsorption) of impurities in a broad spectral range, typically from 400 to $5000 \mathrm{~cm}^{-1}$. Its sensitivity depends primarily on the integral absorption coefficient of the analytical line or band and the intensity of the absorption spectrum of the host substance and impurities in the spectral range in question. The sensitivity of high-resolution IR spectroscopy is typically $10^{-5}$ to $10^{-3}$ mol $\%$ and may rich in some cases $10^{-7}$ to $10^{-6} \mathrm{~mol} \mathrm{\%}[4,5]$.

A literature search revealed no reports on the use of high-resolution FTIR spectroscopy for determining the impurity composition of silicon tetrafluoride or silane. At the same time, IR spectroscopic techniques employing nonvacuum diffraction instruments (with a resolu- 
tion of several $\mathrm{cm}^{-1}$ ) were used in a number of studies [6-9] for semiquantitative analysis of $\mathrm{SiF}_{4}$. In the case of hexafluorodisiloxane, $\mathrm{Si}_{2} \mathrm{~F}_{6} \mathrm{O}$, whose analytical band at $839 \mathrm{~cm}^{-1}$ has a full width at half maximum of about $10 \mathrm{~cm}^{-1}$, this approach is justified if the content of this impurity is no lower than $10^{-2}$ to $10^{-1} \mathrm{~mol} \%$ [6]. At the same time, in the case of light impurities, such as $\mathrm{H}_{2} \mathrm{O}$, $\mathrm{HF}, \mathrm{CO}_{2}$, and $\mathrm{CO}$, whose bands have a rather complex rovibrational structure, the data reported by Sviderskii et al. [8] and Nikonov et al. [9] appear questionable, especially those for water.

In this paper, we examine the possibility of using high-resolution (up to $0.01 \mathrm{~cm}^{-1}$ ) FTIR spectroscopy for determining the impurity composition of isotopically unmodified silicon tetrafluoride and silane prepared from it.

\section{EXPERIMENTAL}

We analyzed the IR spectra of $\mathrm{SiF}_{4}$ and $\mathrm{SiH}_{4}$ samples differing in purity. Note that, to assign impurity bands with more confidence, we also measured the IR spectra of concentrates of high- and low-boiling impurities taken from a fractional column. In addition, we used silane samples prepared by a fluoride-free process.

The IR absorption spectra of silicon tetrafluoride and silane were measured in the range 400 to $4500 \mathrm{~cm}^{-1}$ on a Bruker IFS-120 HR high-resolution vacuum (residual pressure, $\leq 3.9 \mathrm{~Pa}$ ) FTIR spectrometer, with the gas cells constantly kept in the cell compartments. In most measurements, we used a multipass gas cell with a $975-\mathrm{cm}$ pathlength (for studies of silane) and a gas cell with a $20-\mathrm{cm}$ pathlength (for silicon tetrafluoride) made of stainless steel $12 \mathrm{Kh} 18 \mathrm{~N} 10 \mathrm{~T}$, with indium-gasketed $\mathrm{CaF}_{2}$ and $\mathrm{ZnSe}$ windows. Through the leak-in system, passing through a vacuum flange, the cells were connected to turbo and roughing pumps, which ensured a residual pressure in the cells no higher than $130 \mathrm{~Pa}$. The gas pressure in the cells was varied from $1.3 \times 10^{3}$ to $78 \times 10^{3} \mathrm{~Pa}$ and was monitored by an MKS Baratron $722 \mathrm{~A}$ pressure sensor with an accuracy of $0.5 \%$. Spectra were measured with a resolution of 0.01 to $0.1 \mathrm{~cm}^{-1}$ using liquid-nitrogen-cooled MCT and InSb detectors. The signal was acquired over 250-900 scans. Before measurements, we recorded the absorption of evacuated empty cells. The results were subsequently used as a background spectrum, $I_{0}$. Determination of $\mathrm{H}_{2} \mathrm{O}$ and $\mathrm{CO}_{2}$ required more careful, longer time preparation of the experimental setup. In view of this, the instrument and cells were pumped for several days.

In assigning absorption bands and lines of impurities in the gas phase, we used earlier data for $\mathrm{SiF}_{4}$ and $\mathrm{SiH}_{4}[10,11]$, HITRAN Database resources [12] (HF, $\mathrm{H}_{2} \mathrm{O}, \mathrm{CO}, \mathrm{CO}_{2}$, and $\mathrm{CH}_{4}$ molecules), and earlier data for hexafluorodisiloxane, trifluorohydroxysilane, and fluorosilanes [13-21].

In quantitative determination of impurities, we used the standard Bouguer-Lambert-Beer equation:

$$
p=\frac{R T c_{0}}{A l N_{\mathrm{A}}} B
$$

Here, $p$ is the partial pressure of the impurity $(\mathrm{mm} \mathrm{Hg}$ ), $B$ is the integrated intensity of the spectral line or band $\left(\mathrm{cm}^{-1}\right), R=6.236 \times 10^{4} \mathrm{~mm} \mathrm{Hg} \mathrm{cm} /(\mathrm{mol} \mathrm{K})$ is the gas constant, $T$ is the absolute temperature $(\mathrm{K}), c_{0}=$ $2.9979 \times 10^{10} \mathrm{~cm} / \mathrm{s}$ is the velocity of light in vacuum, $A$ is the integral absorption coefficient (IAC) of the line or band $\left(\mathrm{cm}^{2} /(\mathrm{s}\right.$ molecule $\left.)\right), l$ is the optical pathlength $(\mathrm{cm})$, and $N_{\mathrm{A}}=6.022 \times 10^{23} \mathrm{~mol}^{-1}$ is the Avogadro number.

Knowing the partial pressure of an impurity and the total pressure in the cell, one can calculate the percentage of the impurity:

$$
C=p / p_{\text {total }} \times 100 \% .
$$

Here, $C$ is the molar percent of the impurity, $p$ is its partial pressure, and $p_{\text {total }}$ is the total pressure in the cell.

$\mathrm{HF}, \mathrm{H}_{2} \mathrm{O}, \mathrm{CO}, \mathrm{CO}_{2}$, and $\mathrm{CH}_{4}$ impurities, for which reliable values of analytical lines are available, were determined to within $5 \%$ accuracy. For $\mathrm{Si}_{2} \mathrm{~F}_{6} \mathrm{O}, \mathrm{SiF}_{3} \mathrm{OH}$ [14], and fluorosilanes [21], we used the IAC values determined earlier for the entire rovibrational band by first-principles quantum-chemical calculations. This significantly increased the pooled error of determination, which was at least $50 \%$ according to our estimates. The detection limits for the above impurities were estimated using the $3 \sigma$ criterion.

Silicon tetrafluoride was prepared by decomposing sodium hexafluorosilicate and was purified by low-temperature fractional distillation [22]. Silane was synthesized by reacting silicon tetrafluoride with calcium hydride and was then purified by low-temperature fractional distillation [22].

\section{RESULTS AND DISCUSSION}

Figures 1 and 2 show wide-scan IR absorption spectra of silicon tetrafluoride and silane. As seen, the spectra of both compounds contain very strong intrinsic absorption bands in the ranges $950-1350$ and 1750$2100 \mathrm{~cm}^{-1}$ for $\mathrm{SiF}_{4}$ and $1700-2400$ and $700-1200 \mathrm{~cm}^{-1}$ for $\mathrm{SiH}_{4}$. These bands are due to fundamental modes, composite modes, and overtones. The absorption lines of individual impurities lie on the wings of the strongest bands or heavily overlap with them and are, therefore, rather difficult to identify even at the maximum resolution in this study $\left(0.01 \mathrm{~cm}^{-1}\right)$. Consider in greater detail 


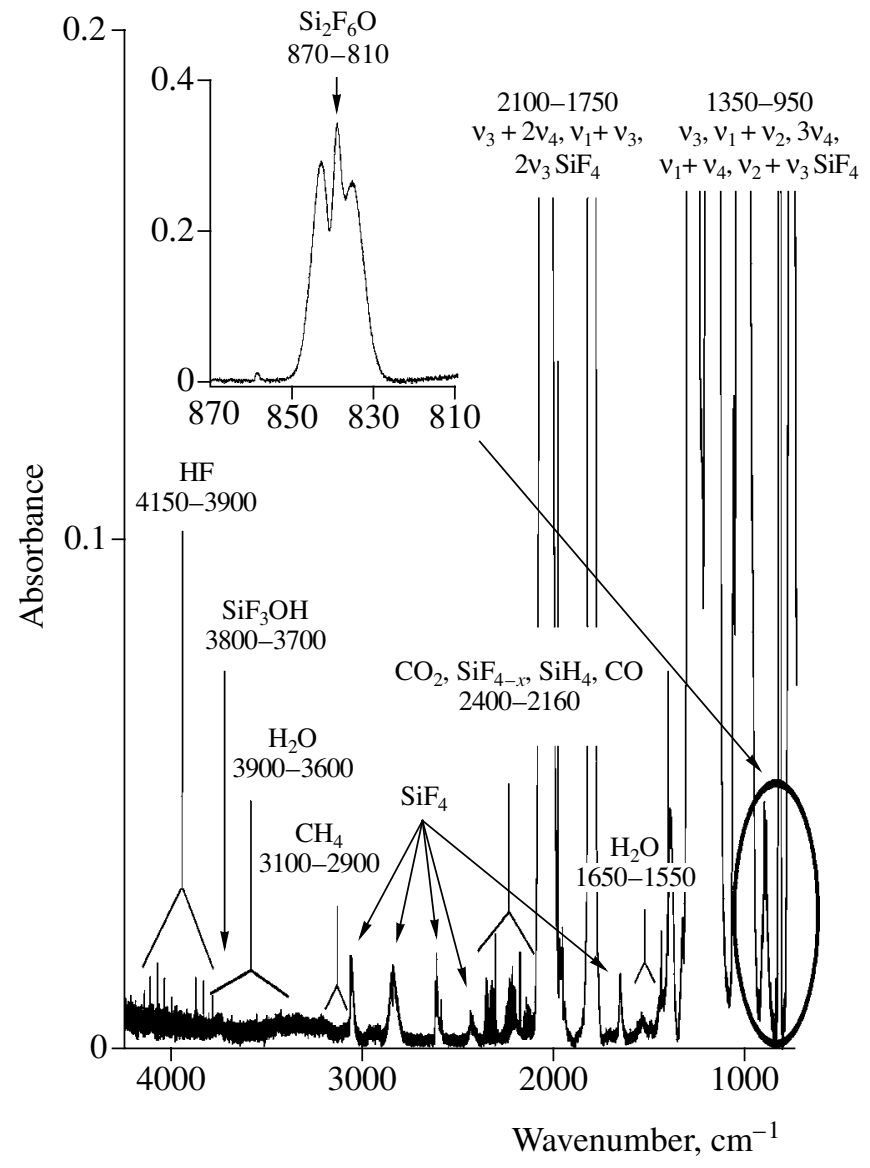

Fig. 1. Absorption spectrum of $\mathrm{SiF}_{4}$ in the range 750$4250 \mathrm{~cm}^{-1}\left(p\left(\mathrm{SiF}_{4}\right)=7.8 \times 10^{4} \mathrm{~Pa}, l=20 \mathrm{~cm}, 0.05-\mathrm{cm}^{-1}\right.$ resolution) showing fundamental and composite absorption bands; the arrows mark impurity absorptions. Inset: absorption band of $\mathrm{Si}_{2} \mathrm{~F}_{6} \mathrm{O}$.

the spectral ranges containing impurity-related absorption lines.

$3950-4150 \mathrm{~cm}^{-1}$. This spectral range includes the $R$ branch of the absorption band of the $v_{1}$ fundamental transition of molecular hydrogen fluoride-one of the major impurities in $\mathrm{SiF}_{4}$ and $\mathrm{SiH}_{4}$. According to Krasnov et al. [23], the absorption band of HF is centered at $3960 \mathrm{~cm}^{-1}$. As seen in Fig. 3, the spectrum of $\mathrm{SiF}_{4}$ before purification shows well-resolved lines at 4109.94, 4075.29, 4038.96, and $4000.99 \mathrm{~cm}^{-1}$, which correspond to an HF content of $(5.0 \pm 0.5) \times 10^{-4} \mathrm{~mol} \%$.

$3600-3900 \mathbf{~ c m}^{-1}$. This spectral range is of interest primarily because it contains absorption lines belonging to the stretching modes $v_{1}$ and $v_{3}$ of molecular water. The content of molecular water in silicon tetrafluoride, a substance highly reactive with moisture, is the subject of much controversy. At the same time, according to preliminary studies of gas-phase $\mathrm{SiF}_{4}$ hydrolysis [14], supplemented later by experiments

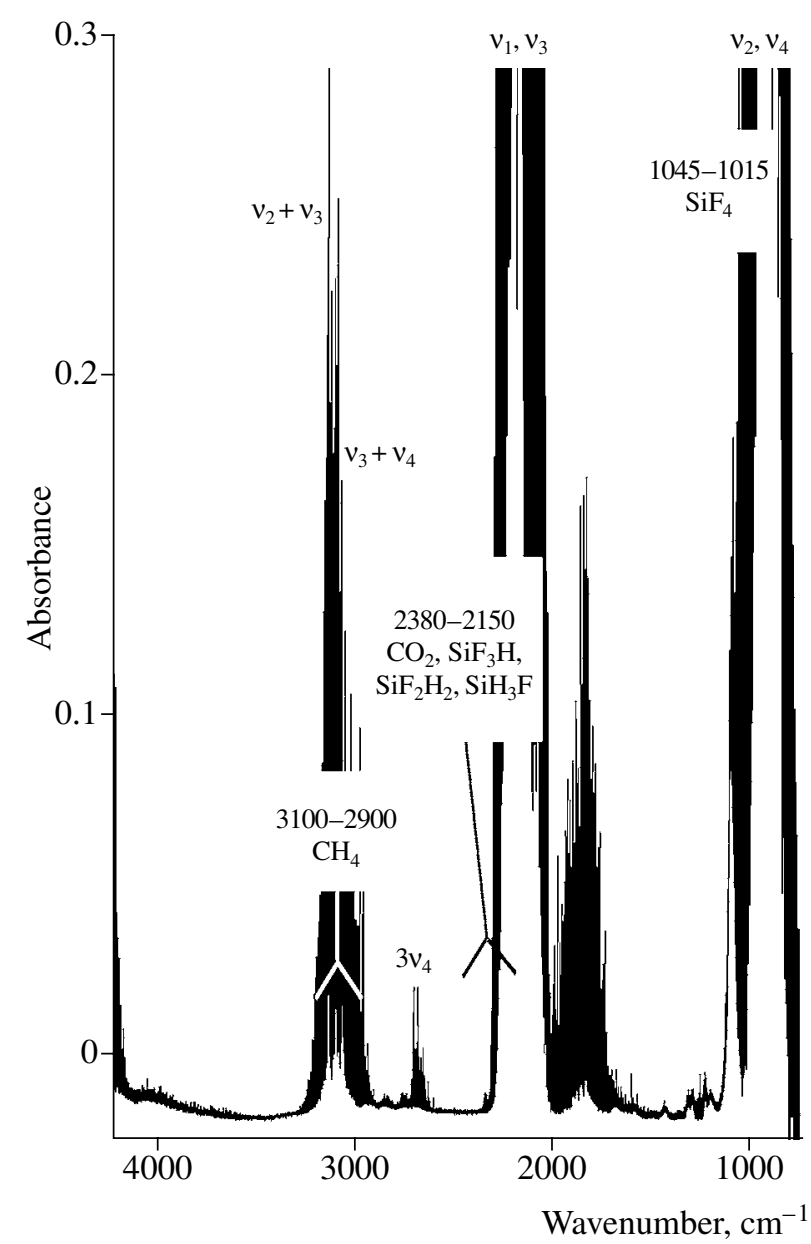

Fig. 2. Absorption spectrum of $\mathrm{SiH}_{4}$ in the range 750$4250 \mathrm{~cm}^{-1}\left(p\left(\mathrm{SiH}_{4}\right)=6.5 \times 10^{3} \mathrm{~Pa}, l=20 \mathrm{~cm}, 0.1-\mathrm{cm}^{-1}\right.$ resolution) showing fundamental and composite absorption bands; the arrows mark impurity absorptions.

with heavy water (the results will be presented in a subsequent communication), a mixture of silicon tetrafluoride and water may be stable for a rather long time. It can be concluded therefore that the portion of the spectrum of water shown in Fig. 4, recorded after the cell and instrument had been treated as described in the EXPERIMENTAL section, is indeed due to the molecular water in silicon tetrafluoride, $(6 \pm 1) \times 10^{-3} \mathrm{~mol} \%$ in this sample. In none of the $\mathrm{SiH}_{4}$ samples studied did we find $\mathrm{H}_{2} \mathrm{O}$ levels above the detection limit in our measurements, $1 \times 10^{-3} \mathrm{~mol} \%$.

According to low-resolution IR spectroscopic studies of impurities in silicon tetrafluoride [24], the spectral range under consideration may contain a band peaked at $3762 \mathrm{~cm}^{-1}$. As shown in detailed experimental and theoretical studies [14], this band is due to stretches of the $\mathrm{OH}$ group of trifluorohydroxysilane, $\mathrm{SiF}_{3} \mathrm{OH}$, forming according to the simplified scheme

$$
\mathrm{SiF}_{4}+\mathrm{H}_{2} \mathrm{O} \longrightarrow \mathrm{SiF}_{3} \mathrm{OH}+\mathrm{HF} .
$$




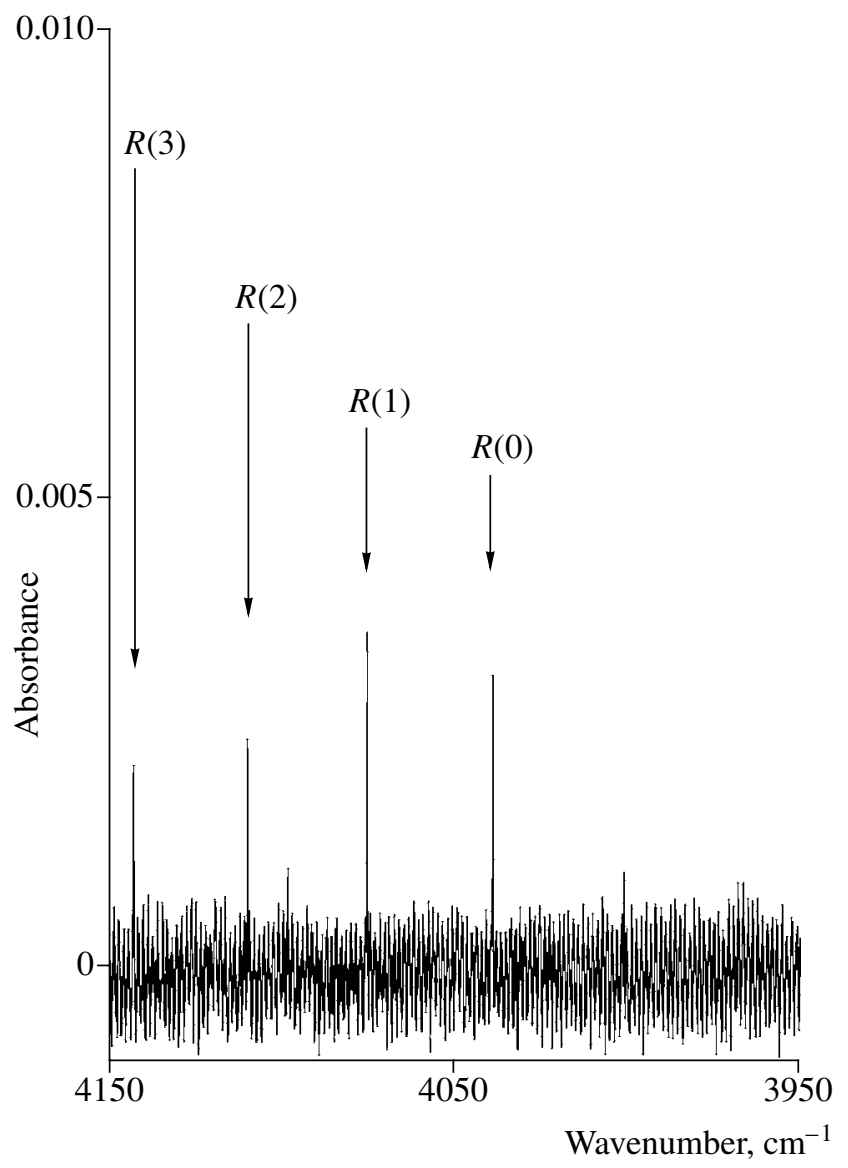

Fig. 3. Portion of the $R$ branch of the rovibrational absorption band $v_{\mathrm{HF}}$ in the spectrum of $\mathrm{SiF}_{4}$ before purification $\left(p\left(\mathrm{SiF}_{4}\right)=2.6 \times 10^{3} \mathrm{~Pa}, l=975 \mathrm{~cm}, 0.01-\mathrm{cm}^{-1}\right.$ resolution $)$ and positions of analytical rotational lines (4000.99, 4038.96, 4075.29, and $4109.94 \mathrm{~cm}^{-1}$ ).

The formation of this intermediate in silicon tetrafluoride hydrolysis is typical of unpurified $\mathrm{SiF}_{4}$. The $\mathrm{SiH}_{4}$ samples showed no impurity-related absorption in the spectral range in question.

$2800-3200 \mathrm{~cm}^{-1}$. This spectral range includes rovibrational components of stretching modes of light hydrocarbons, $\mathrm{C}_{1}-\mathrm{C}_{4}$. The strongest lines belong to the stretching mode $v_{3}$ of methane [12]. Several of our silicon tetrafluoride samples contained $\mathrm{CH}_{4}$, at a level no higher than $1 \times 10^{-3} \mathrm{~mol} \%$, even in impurity concentrates.

Rovibrational lines of methane impurity in silane are difficult to reveal because the stretching band $v_{3}$ of methane overlaps with the $v_{2}+v_{3}$ and $v_{3}+v_{4}$ absorption bands of $\mathrm{SiH}_{4}$. In view of this, to identify the absorption bands of methane impurity in silane we used the spectrum, taken under the same conditions, of silane prepared by a fluoride-free process.

Figure 5 shows a portion of the spectrum of silane prepared by a fluoride-free process and containing $\mathrm{CH}_{4}$

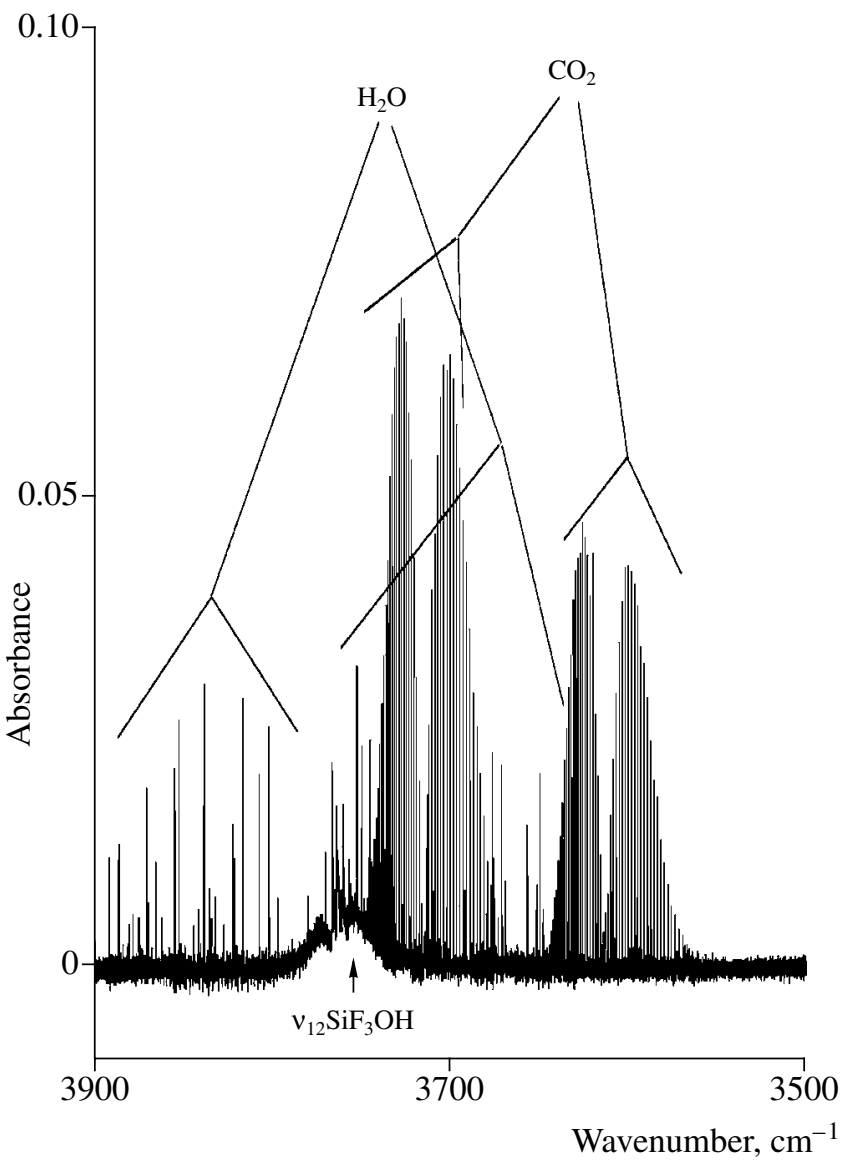

Fig. 4. Rovibrational absorption bands of $\mathrm{H}_{2} \mathrm{O}\left(\mathrm{v}_{1}\right.$ and $\left.\mathrm{v}_{3}\right)$, $\mathrm{CO}_{2}$ (Fermi-resonance bands), and $\mathrm{SiF}_{3} \mathrm{OH}\left(v_{12}\right.$ at $\left.3762 \mathrm{~cm}^{-1}\right)$ impurities in $\mathrm{SiF}_{4}$ before purification; $p\left(\mathrm{SiF}_{4}\right)=$ $5.8 \times 10^{3} \mathrm{~Pa}, l=975 \mathrm{~cm}, 0.01-\mathrm{cm}^{-1}$ resolution.

at a level no higher than a few times $10^{-6} \mathrm{~mol} \%$ (according to gas chromatography data) (curve 1), a portion of the spectrum of silane prepared from $\mathrm{SiF}_{4}$ with no subsequent purification (curve 2), and the difference spectrum of curves 1 and 2 (curve 3). The resultant spectrum is in perfect agreement with the reference spectrum for this portion of the $v_{3}$ band of silane [12]. According to our data, the methane content of the sample is $(8 \pm 4) \times 10^{-3} \mathrm{~mol} \%$, in good agreement with the gas chromatography results.

$2100-2400 \mathbf{~ c m}^{-1}$. This spectral range is rather informative for assessing the impurity compositions of silicon tetrafluoride and silane because it includes the following absorption bands of typical impurities:

$2349.5 \mathrm{~cm}^{-1}$, the $v_{3}$ band of carbon dioxide, $\mathrm{CO}_{2}[12]$;

$2316.7 \mathrm{~cm}^{-1}$, the $v_{1}$ band of trifluorosilane, $\mathrm{SiF}_{3} \mathrm{H}$ $[15,16]$;

$2251.6 \mathrm{~cm}^{-1}$, the $v_{1}$ band of difluorosilane, $\mathrm{SiF}_{2} \mathrm{H}_{2}[17]$; 


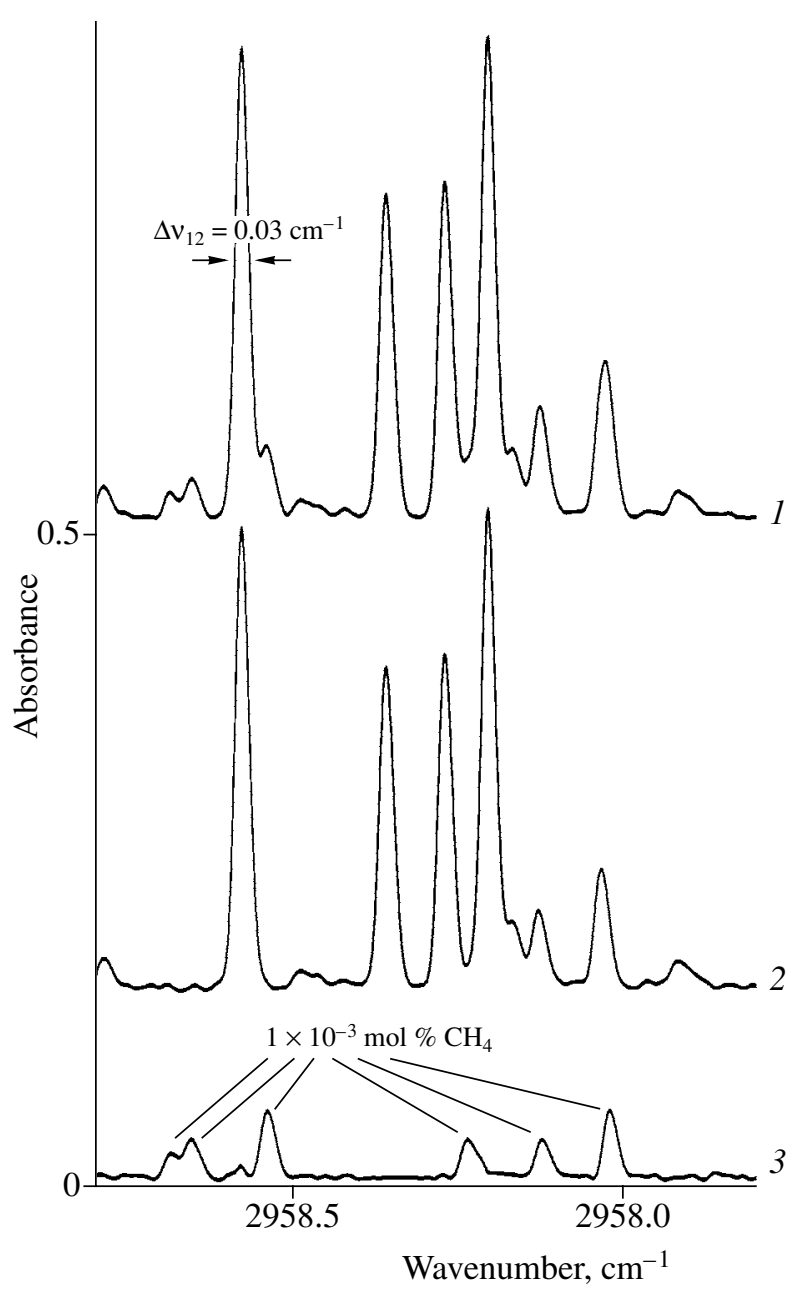

Fig. 5. Rotational components of the rovibrational absorption band $v_{3}$ of $\mathrm{SiF}_{4}$ impurity in $\mathrm{SiH}_{4}\left(p\left(\mathrm{SiH}_{4}\right)=1.3 \times\right.$ $10^{3} \mathrm{~Pa}, l=975 \mathrm{~cm}, 0.01-\mathrm{cm}^{-1}$ resolution): (1) $\mathrm{SiH}_{4}$ sample prepared from $\mathrm{SiF}_{4}$ with no subsequent purification, (2) $\mathrm{SiH}_{4}$ sample prepared by a fluoride-free process and containing $\mathrm{CH}_{4}$ at a level no higher than a few times $10^{-6} \mathrm{~mol} \%$, (3) difference spectrum of curves 1 and 2 .

$2216.8 \mathrm{~cm}^{-1}$, the $v_{1}$ band of fluorosilane, $\mathrm{SiFH}_{3}[18-20]$;

$2143 \mathrm{~cm}^{-1}$, the band of carbon monoxide, CO [12].

In addition to these impurities in silicon tetrafluoride, this spectral range includes the $v_{1}$ band of $\mathrm{SiH}_{4}$, centered at $2188 \mathrm{~cm}^{-1}$. This, in turn, impedes determination of impurities in silane. Figure 6 shows a portion of the spectrum of an $\mathrm{SiF}_{4}$ sample containing all of the above impurities.

In the case of silane, of all the above impurities only $\mathrm{CO}_{2}$ is sufficiently easy to identify, owing to the absorption in the range $2350-2400 \mathrm{~cm}^{-1}$, where the absorption in silane is very weak. The analytical range $2150-2350 \mathrm{~cm}^{-1}$ of fluorosilanes overlaps almost entirely with the strong absorption lines of silane. As a

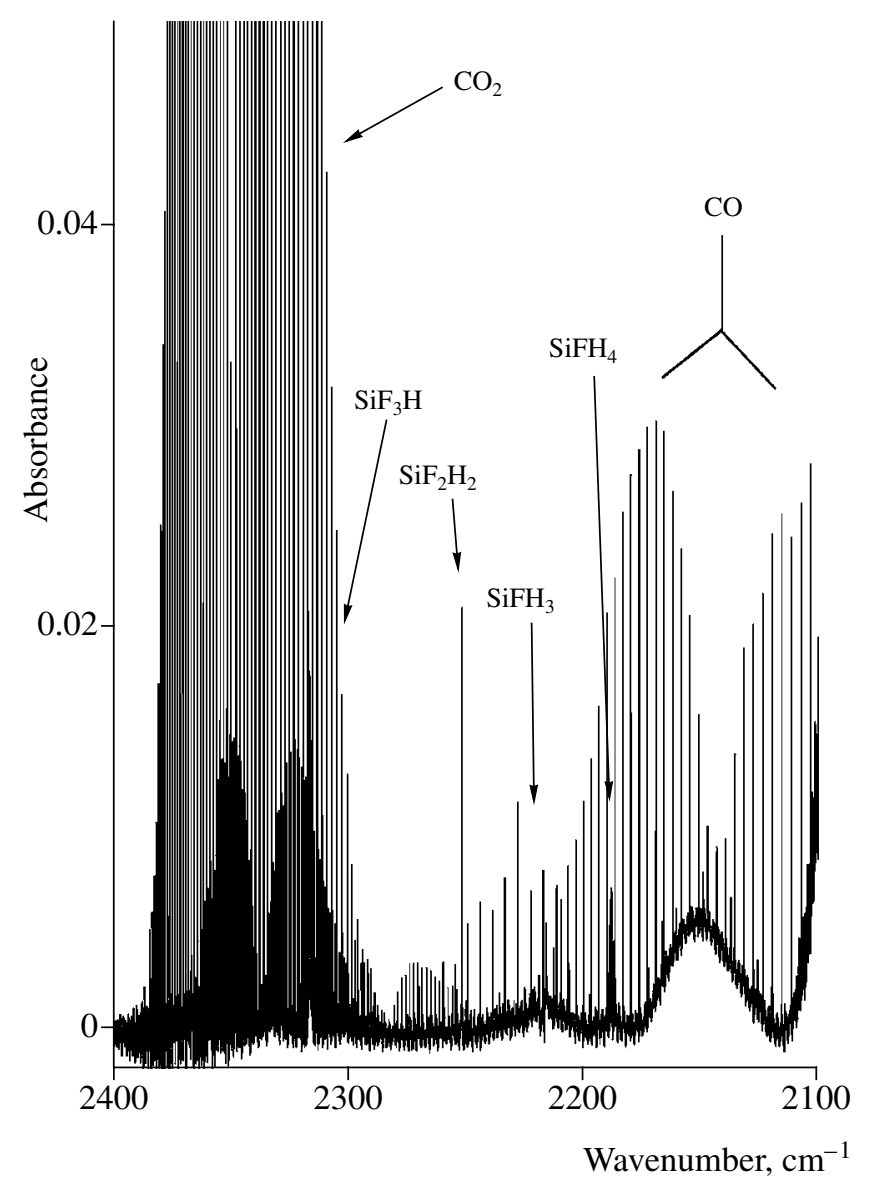

Fig. 6. Rovibrational bands of $\mathrm{CO}_{2}\left(v_{3}\right), \mathrm{SiF}_{3} \mathrm{H}\left(v_{1}\right), \mathrm{SiF}_{2} \mathrm{H}_{2}$ $\left(v_{1}\right), \mathrm{SiFH}_{3}\left(v_{1}\right), \mathrm{SiH}_{4}\left(v_{1}\right)$, and $\mathrm{CO}\left(v_{1}\right)$ impurities in a concentrate taken from the top part of a fractional column; $p\left(\mathrm{SiF}_{4}\right)=4.7 \times 10^{3} \mathrm{~Pa}, l=975 \mathrm{~cm}, 0.01-\mathrm{cm}^{-1}$ resolution .

result, only the absorption in trifluorosilane, $\mathrm{SiF}_{3} \mathrm{H}$, may be identified with certainty. Using the above-mentioned procedure-subtraction of the spectrum of silane prepared by a fluoride-free process from that of "fluoride" silane-we obtained the $v_{1}$ band of trifluorosilane with a well-defined $R-Q-P$ profile (Fig. 7). The $\mathrm{SiF}_{3} \mathrm{H}$ content of silane samples prepared from silicon tetrafluoride varied from $(8 \pm 6) \times 10^{-2}$ to $(1 \pm 0.7) \times$ $10^{-2} \mathrm{~mol} \%$.

1500-1700 $\mathbf{c m}^{-1}$. This spectral range includes absorption lines of the $v_{2}$ bending mode of water molecules, whose behavior in $\mathrm{SiF}_{4}$ and $\mathrm{SiH}_{4}$ was mentioned above. At the same time, it lies within the transmission window of silicon tetrafluoride, so that the absorption lines in this range can be used as analytical. Note, however, that the MCT detector used in this spectral range ensured a notably smaller signal-to-noise ratio in comparison with the range $3600-3900 \mathrm{~cm}^{-1}$ (InSb detector) at the same signal intensity. 


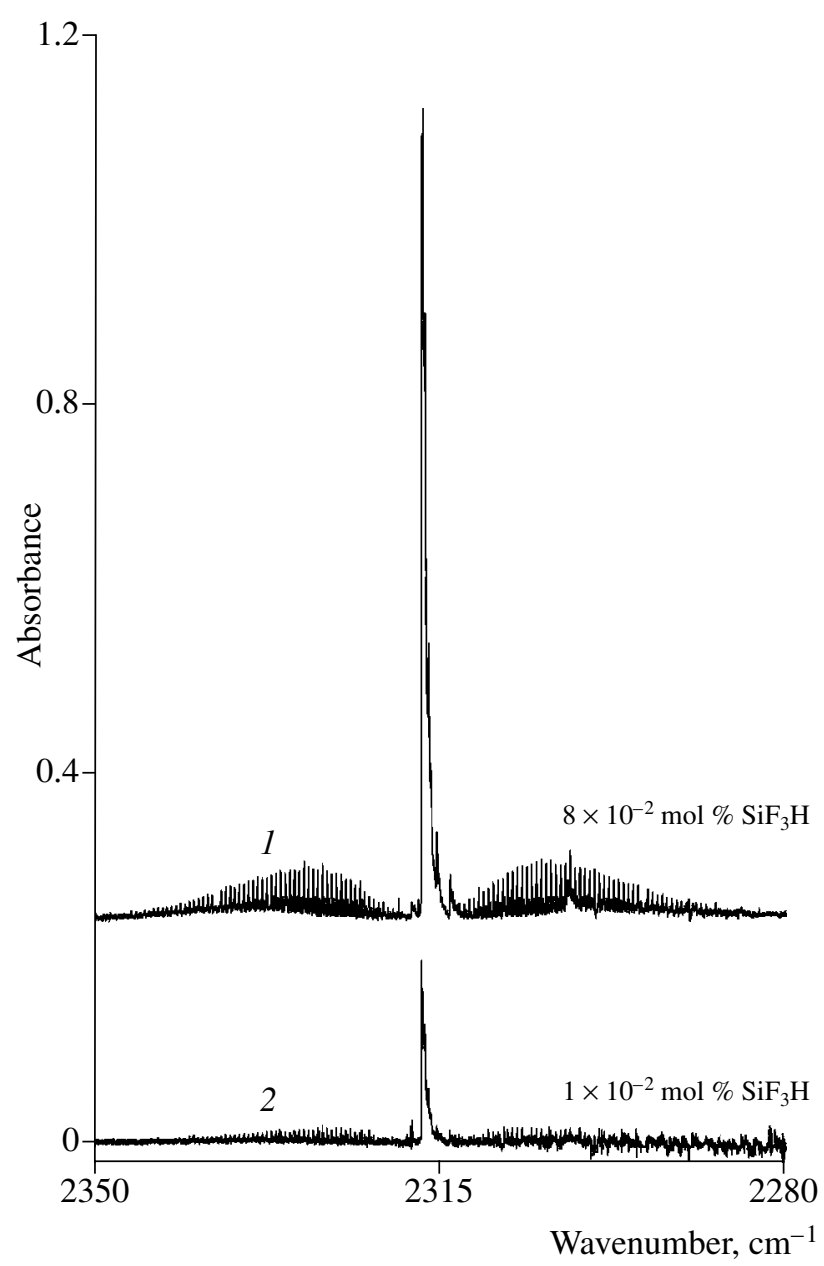

Fig. 7. Rovibrational band $v_{1}$ of $\mathrm{SiF}_{3} \mathrm{H}$ in $\mathrm{SiH}_{4}$ samples (1) before and (2) after purification; $p\left(\mathrm{SiH}_{4}\right)=1.3 \times 10^{3} \mathrm{~Pa}$, $l=975 \mathrm{~cm}, 0.01-\mathrm{cm}^{-1}$ resolution.

1015-1045 $\mathbf{~ c m}^{-1}$. This range can be used for determination of silicon tetrafluoride impurities in silane owing to the very strong band at $1031.4 \mathrm{~cm}^{-1}$. The IAC of this band has been recently refined by Burtsev et al. [25]. The detection limit of $\mathrm{SiF}_{4}$ might be lower by at least one order of magnitude, but this is prevented by the overlap of the analytical band at $1031.4 \mathrm{~cm}^{-1}$ with the bending bands $v_{2}$ and $v_{4}$ of silane.

$800-880 \mathrm{~cm}^{-1}$. The strongest band in this spectral range is the $v_{14}$ band (centered at $839 \mathrm{~cm}^{-1}$ ) of hexafluorodisiloxane, $\mathrm{Si}_{2} \mathrm{~F}_{6} \mathrm{O}$, a product of partial silicon tetrafluoride hydrolysis [6, 13] (Fig. 8). This substance is among the most important oxygen-containing impurities in silicon tetrafluoride and was found in all of the silicon tetrafluoride samples studied here. In the spectra of the silane prepared from silicon tetrafluoride, this impurity was not detected.

The table summarizes the analytical results for the impurities in silicon tetrafluoride and silane samples

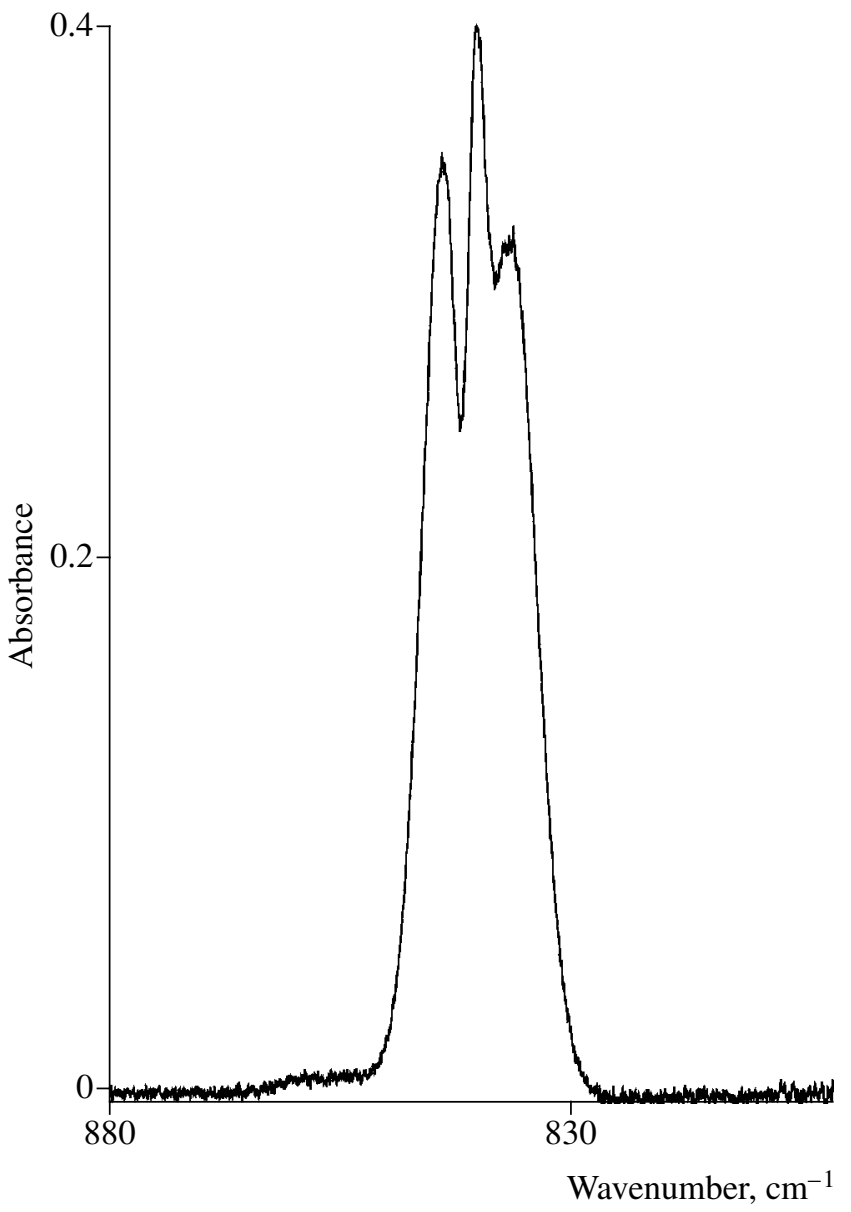

Fig. 8. Absorption band of $\mathrm{Si}_{2} \mathrm{~F}_{6} \mathrm{O}$ in $\mathrm{SiF}_{4}$ in the range $850-900 \mathrm{~cm}^{-1} ; p\left(\mathrm{SiF}_{4}\right)=6.5 \times 10^{3} \mathrm{~Pa}, l=10 \mathrm{~cm}, 0.05-\mathrm{cm}^{-1}$ resolution.

differing in purity. Note that high-resolution FTIR spectroscopy is currently the only tool for simultaneous determination of $\mathrm{H}_{2} \mathrm{O}, \mathrm{Si}_{2} \mathrm{~F}_{6} \mathrm{O}$, and $\mathrm{SiF}_{3} \mathrm{OH}$ in $\mathrm{SiF}_{4}$ and $\mathrm{SiH}_{4}$ at impurity concentrations low enough for practical applications. This technique offers a rather low detection limit of $\mathrm{CO}_{2}$ and enables determination of a number of fluorine-containing impurities, which is crucial for the successful implementation of the technology in question. Unfortunately, in the case of fluorosilanes the error of determination is rather large, first, because of the strong intrinsic absorption in $\mathrm{SiF}_{4}$ and $\mathrm{SiH}_{4}$ in the spectral ranges in question and, second, because of the use of IACs found by quantum-chemical calculations $[14,21]$, which are known to be still inferior in accuracy to experimental techniques. On the other hand, according to our results the total content of fluorine in the form of fluorine-containing molecules (excluding difluorosilane) in the silane sample is $0.12 \mathrm{~mol} \%$, which is in reasonable agreement with chromatography data $(0.17 \mathrm{~mol} \%)$ [23]. Moreover, IR 
Impurity compositions of $\mathrm{SiF}_{4}$ and $\mathrm{SiH}_{4}$ samples before and after purification

\begin{tabular}{l|c|c|c|c|c}
\hline \multirow{2}{*}{ Impurity } & \multicolumn{4}{|c|}{ Molar percent } & \multirow{2}{*}{ DL, mol \% } \\
\cline { 2 - 5 } & \multicolumn{2}{|c|}{$\mathrm{SiF}_{4}$} & \multicolumn{2}{c}{$\mathrm{SiH}_{4}$} \\
\cline { 2 - 5 } & before purification & after purification & before purification & after purification & \\
\hline $\mathrm{Si}_{2} \mathrm{~F}_{6} \mathrm{O}$ & $2 \pm 1$ & $0.2 \pm 0.1$ & $<\mathrm{DL}$ & $<\mathrm{DL}$ & $1 \times 10^{-3}$ \\
$\mathrm{SiF}_{3} \mathrm{OH}$ & $(2 \pm 1) \times 10^{-2}$ & $<\mathrm{DL}$ & $<\mathrm{DL}$ & $<\mathrm{DL}$ & $1 \times 10^{-3}$ \\
$\mathrm{HF}$ & $(5.0 \pm 0.5) \times 10^{-4}$ & $<\mathrm{DL}$ & $<\mathrm{DL}$ & $<\times 10^{-4}$ \\
$\mathrm{H}_{2} \mathrm{O}$ & $(6 \pm 1) \times 10^{-3}$ & $<\mathrm{DL}$ & $<\mathrm{DL}$ & $<\mathrm{DL}$ & $1 \times 10^{-3}$ \\
$\mathrm{SiH}_{4}$ & $<\mathrm{DL}$ & $<\mathrm{DL}$ & & & $1 \times 10^{-3}$ \\
$\mathrm{SiF}_{3} \mathrm{H}$ & $(4 \pm 2) \times 10^{-3}$ & $<\mathrm{DL}$ & $(8 \pm 6) \times 10^{-2}$ & $(1.0 \pm 0.7) \times 10^{-2}$ & $1 \times 10^{-3}$ \\
$\mathrm{SiF}_{2} \mathrm{H}_{2}$ & $(2 \pm 1) \times 10^{-3}$ & $<\mathrm{DL}$ & $\mathrm{NA}$ & $\mathrm{NA}$ & $1 \times 10^{-3}$ \\
$\mathrm{SiH}_{3} \mathrm{~F}$ & $\leq \mathrm{DL}$ & $<\mathrm{DL}$ & $(7 \pm 5) \times 10^{-2}$ & $(3 \pm 2) \times 10^{-3}$ & $1 \times 10^{-3}$ \\
$\mathrm{SiF}_{4}$ & & $(6 \pm 4) \times 10^{-3}$ & $<\mathrm{DL}$ & $5 \times 10^{-4}$ \\
$\mathrm{CH}_{4}$ & $\leq \mathrm{DL}$ & $<\mathrm{DL}$ & $(8 \pm 4) \times 10^{-3}$ & $<\mathrm{DL}$ & $1 \times 10^{-3}$ \\
$\mathrm{CO}_{2}$ & $(5.0 \pm 0.5) \times 10^{-2}$ & $(3 \pm 0.3) \times 10^{-3}$ & $(4 \pm 0.5) \times 10^{-4}$ & $<\mathrm{DL}$ & $8 \times 10^{-5}$ \\
$\mathrm{CO}$ & $(4.0 \pm 0.4) \times 10^{-3}$ & $\leq \mathrm{DL}$ & $\mathrm{NA}$ & $\mathrm{NA}$ & $1 \times 10^{-3}$ \\
\hline
\end{tabular}

Note: $\mathrm{DL}=$ detection limit, $\mathrm{NA}=$ not analyzed.

spectroscopy offers the possibility of identifying the chemical nature of impurities.

\section{CONCLUSIONS}

High-resolution FTIR spectroscopy can be used to analyze the impurity composition of silicon tetrafluoride and silane prepared from it. Using this technique, we detected a variety of impurities in $\mathrm{SiF}_{4}$ samples of different purity: $\mathrm{SiF}_{3} \mathrm{H}, \mathrm{SiF}_{2} \mathrm{H}_{2}, \mathrm{SiH}_{3} \mathrm{~F}, \mathrm{CH}_{4}, \mathrm{CO}_{2}, \mathrm{CO}$, and the products of partial $\mathrm{SiF}_{4}$ hydrolysis under the action of moisture $\left(\mathrm{HF}, \mathrm{SiF}_{3} \mathrm{OH}, \mathrm{Si}_{2} \mathrm{~F}_{6} \mathrm{O}\right.$, and molecular water). $\mathrm{H}_{2} \mathrm{O}$ and $\mathrm{SiF}_{3} \mathrm{OH}$ impurities in silicon tetrafluoride were detected with certainty for the first time. The detection limits of these impurities lie in the range $9 \times$ $10^{-5}\left(\mathrm{CO}_{2}\right)$ to $3 \times 10^{-3} \mathrm{~mol} \%\left(\mathrm{Si}_{2} \mathrm{~F}_{6} \mathrm{O}\right)$. In $\mathrm{SiH}_{4}$ samples of different purity, we detected $\mathrm{CH}_{4}, \mathrm{CO}_{2}, \mathrm{SiF}_{3} \mathrm{H}$, $\mathrm{SiF}_{2} \mathrm{H}_{2}$, and $\mathrm{SiF}_{4}$ impurities. Their detection limits lie in the range $8 \times 10^{-5}\left(\mathrm{CO}_{2}\right)$ to $1 \times 10^{-3} \mathrm{~mol} \%\left(\mathrm{SiF}_{4}\right)$.

\section{REFERENCES}

1. Guzeev, V. V., Grishkov, V. N., and D'yachenko, A. N., Integrated Recycling of Silicon Tetrafluoride and Zirconia, Zh. Prikl. Khim. (S.-Peterburg), 2003, vol. 76, no. 12, pp. 1952-1955.

2. Loginov, A.V. and Garbar, A.M., Silicon Tetrafluoride: Properties, Preparation, and Application, Vysokochist. Veshchestva, 1989, no. 5, pp. 27-34.

3. Devyatykh, G.G., Bulanov, A.D., Gusev, A.V., et al., Preparation of High-Purity ${ }^{28} \mathrm{Si}$, Dokl. Akad. Nauk, 2001, vol. 376, no. 4, pp. 492-493.
4. Pivonka, D.E., The Infrared Spectroscopic Determination of Moisture in $\mathrm{HCl}$ for the Characterization of $\mathrm{HCl}$ Gas Drying Resin Performance, Appl. Spectrosc., 1991, vol. 45, no. 4, pp. 597-603.

5. Andreev, B.A. and Devyatykh, G.G., Determination of Water in High-Purity Oxygen by IR Absorption Spectroscopy, Vysokochist. Veshchestva, 1989, no. 4, pp. 161-166.

6. Reents, W.D., Wood, D.L., and Mujsce, A.M., Impurities in Silicon Tetrafluoride Determined by Infrared Spectrometry and Fourier Transform Mass-Spectrometry, Anal. Chem., 1985, vol. 57, no. 1, pp. 104-109.

7. Novikova, V.G., Krivosheev, N.V., Alekseev, O.G., et al., IR Spectroscopic Determination of Impurities in Silicon Tetrafluoride, Sb. Nauchn. Tr. Vses. Nauchno-Issled. Inst. Lyuminoforov Osobo Chist. Vechshest, 1987, no. 33, pp. 158-164.

8. Sviderskii, M.F., Khozorova, O.D., Dovganich, G.I., and Ivanova, V.A., Molecular State of Impurities in Silicon Tetrafluoride, Vysokochist. Veshchestva, 1994, no. 1, pp. 130-133.

9. Nikonov, V.I., Sviderskii, M.F., Kvaratskheli, Yu.K., and Khorozova, O.D., Synthesis and Purification of Silicon Tetrafluoride and Boron Trifluoride, Tsvetn. Met. (Moscow), 2003, no. 4, pp. 75-77.

10. McDowell, R.S., Reisfeld, M.J., et al., Infrared Spectrum and Potential Constants of Silicon Tetrafluoride, J. Chem. Phys., 1982, vol. 77, no. 9, pp. 4337-4343.

11. Patterson, C.W., McDowell, R.S., et al., Tunable Laser Diode Study of the $\mathrm{v}_{3}$ Band of $\mathrm{SiF}_{4}$ near $9.7 \mu \mathrm{m}, \mathrm{J}$. Mol. Spectrosc., 1982, vol. 91, no. 2, pp. 416-423.

12. Rothman, L.S., Rinsland, C.P., et al., The HITRAN Molecular Spectroscopic Database and HAWKS (HITRAN Atmospheric Workstation): 1996 Edition, J. 
Quant. Spectrosc. Radiat. Transfer, 1998, vol. 60, no. 5, pp. 665-710.

13. Durig, J.R., Kalasinsky, V.F., and Flanagan, M.J., Spectra and Structure of Some Silicon-Containing Compounds: VIII. Vibrational Spectra of Hexafluorodisiloxane, Inorg. Chem., 1975, vol. 14, no. 11, pp. 2839-2845.

14. Ignatov, S.K., Sennikov, P.G., Chuprov, L.A., and Razuvaev, A.G., Thermodynamic and Rate Parameters of Silicon Tetrafluoride Hydrolysis, Izv. Akad. Nauk, Ser. Khim., 2003, no. 4, pp. 797-805.

15. Newman, C., Polo, S.R., and Wilson, M.K., Infrared Spectra of $\mathrm{SiF}_{3} \mathrm{H}, \mathrm{SiF}_{3} \mathrm{D}, \mathrm{SiD}_{3} \mathrm{~F}$, and $\mathrm{SiD}_{3} \mathrm{Cl}$, Spectrochim. Acta, 1959, vol. 10, pp. 793-799.

16. Bürger, H., Biedermann, S., and Ruoff, A., Schwingungsspektren und Kraftkonstanten symmetrischer Kreisel-V. Die IR-Spektren von $\mathrm{HSiF}_{3}$ und $\mathrm{DSiF}_{3}$, Spectrochim. Acta, 1971, vol. 27, no. 9, pp. 1687-1702.

17. D'Eu, J.-F., Demaison, J., and Burger, H., MillimeterWave and High-Resolution FTIR Spectroscopy of $\mathrm{SiH}_{2} \mathrm{~F}_{2}$ : The Ground and $v_{4}=1$ States, J. Mol. Spectrosc., 2003, vol. 218, no. 1, pp. 12-21.

18. Newman, C., Kenneth O'Loane, J., et al., Infrared Spectra and Molecular Structures of $\mathrm{SiH}_{3} \mathrm{~F}, \mathrm{SiH}_{3} \mathrm{Cl}$, and $\mathrm{SiH}_{3} \mathrm{Br}$, J. Chem. Phys., 1956, vol. 25, no. 5, pp. 855-859.

19. Robiette, A.G., Cartwright, G.J., et al., The Infra-red Spectra of Silyl Fluoride and Silyl Fluoride- $d_{3}, \mathrm{Mol}$. Phys., 1971, vol. 20, no. 3, pp. 541-553.
20. Bürger, H. and Schulz, P., The High-Resolution Fourier Transform Infrared Spectrum of $\mathrm{H}_{3} \mathrm{SiF}$ near $2200 \mathrm{~cm}^{-1}$ : Rovibrational Analysis of the Fundamentals $v_{1}$ and $v_{4}$ and Their Perturbers $3 v_{6}^{ \pm 1}$ and $3 v_{6}^{ \pm 3}$, J. Mol. Spectrosc., 1987, vol. 125, no. 1, pp. 140-153.

21. Ignatov, S.K., Sennikov, P.G., Razuvaev, A.G., et al., Quantum-Chemical Study of the Structural, Spectral, and Electro-optical Parameters of the $\mathrm{SiH}_{4-x} \mathrm{~F}_{x}(x=$ 0-4) Fluorosilanes, Opt. Spektrosk., 2001, vol. 90, no. 5, pp. 732-742.

22. Bulanov, A.D., Balabanov, V.V., Pryakhin, D.A., and Troshin, O.Yu., Preparation and Fine Purification of $\mathrm{SiF}_{4}$ and ${ }^{28} \mathrm{SiH}_{4}$, Neorg. Mater, 2002, vol. 38, no. 3, pp. 356-361 [Inorg. Mater. (Engl. Transl.), vol. 38, no. 3, pp. 283-287].

23. Krasnov, K.S, Timoshinin, V.S., Danilova, T.G., and Khandozhko, S.V., Molekulyarnye postoyannye neorganicheskikh soedinenii (Molecular Constants of Inorganic Compounds), Moscow: Khimiya, 1968.

24. Sennikov, P.G., Ikrin, M.A., Ignatov, S.K., et al., IRSpectroscopic and Quantum-Chemical Studies of the Products of Silicon Tetrafluoride Hydrolysis at Low Water Concentrations, Izv. Akad. Nauk, Ser. Khim., 1999, no. 48, pp. 93-97.

25. Burtsev, A.P., Bocharov, V.N., et al., Integrated Intensities of Absorption Bands in Silicon Tetrafluoride in the Gas Phase and Cryogenic Solutions: Experiment and Calculation, Opt. Spektrosk., 2005, vol. 98, no. 2, pp. 261-268. 